Ann. Biol. anim. Bioch. Biophys., 1979, 19 (4 B), 1251-1261.

\title{
Regulation of meiosis in mammals
}

par Anne Grete BYSKOV

The Finsen Laboratory, The Finsen Institufe,

Strandboulevarden 49, 2100 Copenhagen Ø., DK-Denmark.

Summary. Culture media which contain either substances that can induce meiosis (meiosis-inducing substances, MIS) or prevent meiosis (meiosis-preventing substances, MPS) can be obtained from different experiments.

$M I S$ is present in culture media in which tissues of ovaries with germ cells in meiosis, or fetal epididymis, or puberal epididymis and testes, have grown. MIS is apparently species-nonspecific since media containing MIS obtained from puberal bulls induce meiosis in indifferent fetal mouse testes.

MPS is secreted into the culture media of minced fetal mouse testes. Meiosis si prevented or greatly inhibited in fetal mouse ovaries, when they are cultured in such media.

It was concluded that MIS was present in mesonephric derived tissues in gonads in which meiosis occurred. Moreover, MPS within the testicular tissue (within the testicular cords ?) might participate in preventing meiosis in the fetal testis.

However, a negative «MIS-activity-test» result was obtained in an experiment with rabbit gonads : meiosis was not induced in fetal gonads by infant ovarian tissue containing germ cells in meiosis. This led to comparative investigations of gonads from species in which the onset of meiosis and gonadal sex differentiation coincide in time, « simultaneous meiosis », and those, like the rabbit, in which the onset of meiosis in the female is delayed, « delayed meiosis ». In species with « delayed meiosis» the germ cells were confined to cord-like structures during the period between differentiation and the onset of meiosis. Within that period these species also produced sex steroids. In species with « simultaneous meiosis 》 the female germ cells were distributed freely within the corlex, and no sex steroid hormones were produced in the period following sex differentiation. The significance of these features are discussed in relation to regulation of meiosis.

\section{Introduction.}

The process of germ cell differentiation seems to be closely related to gonadal organogenesis and differentiation. As pointed out by Jost (1965) a simple explanation of gonadal sex differentiation would be that the $Y$-chromosome imposed differentiation into a testis, and that the lack of the gene for maleness automatically causes the formation of an ovary. Testicular differentiation invariably leads to enclosure of gonocytes within testicular cords and synthesis of testosterone (Jost, 1972). At the corresponding stage of differentiation the oogonia lie freely within the supporting tissue of the ovarian anlage. 
When confined to the testicular cords the male germ cells enter the period of prespermatogenesis (Hilscher and Makoski, 1968). During the first part of this period the gonocytes multiply. Thereafter follows a quiescent period without mitotic divisions. Finally the germ cells enter a second wave of mitosis preceding meiosis at puberty. Although the different periods of prespermatogenesis vary between species, this dynamic pattern generally seems to be valid for the mammalian male germ cells (Gondos, 1977).

In females of different species the germ cells do not always follow the same dynamic pattern during the period after the gonadal sex is morphologically distinguishable. In some species, such as humans and mice, sex differentiation and the appearence of the first meiotic germ cells are almost simultaneous while in others, as rabbits and ewes, the two events are far separated in time (for review, see Mauléon, 1969).

In the following, substances including sex steroid hormones, which may participate in the regulation of the meiotic initiation, will be discussed in relation to different patterns of gonadal differentiation.

\section{Induction of meiosis in males.}

The first germ cells which enter leptotene stage are normally first seen in the young pre-puberal testis. However, in many species preleptotene condensation stages are present a long time before puberty (Luciani ef al., 1977). Moreover, there are several circumstances in which the XY-germ cells - when placed in conditioned environments - can be induced to enter meiosis early in life. Gonocytes left outside the testicular cords during gonadal differentiation of the fetal mouse, enter meiosis if they are situated close to the rete testis or to the developing epididymis (Byskov, 1978a). That the rete testis and the epididymis in fact are responsible for this early induction of meiosis was indicated by the following results of cultured fetal mouse gonads : when the indifferent testes grow in a media in which fetal epididymis previously has been cultured, numerous male germ cells situated close to the gonadal surface enter meiosis (Byskov, 1978b). We have concluded that this medium contains a meiosis inducing substance, MIS. Also tissues of puberal epididymis and testes of mice and bulls secrete MIS, which is able to induce meiosis in the indifferent mouse testes (Grinsted, Byskov and Andreasen, 1979). Induction of meiosis was also seen in transplants of embryonic mouse testes (Ozdzenski, 1972) and in cultured fetal testes paired with rete containing ovaries with germ cells in meiosis of coeval or older ages (mouse : Byskov and Saxen, 1976 ; hamster : O and Baker, 1976).

\section{Prevention of meiosis in males.}

The fact that the fetal male germ cells of some species are able to enter meiosis and that an active MIS is present in the rete testis and epididymis indicate, that fetal male germ cells are prevented from entering meiosis rather than lacking a stimulus. Several authors have suggested that the male germ cells are inhibited from entering meiosis by some influences of the somatic tissues (Tarkowski, 1969 ; Jost, 1970, 1974 ; McLaren, Chandley and Koffman-Alfaro, 1973).

A meiosis-preventing influence could be obtained from culture media in which testicular tissues of fetal mice had grown (Byskov, 1978b). When differentiating fetal 
mouse ovaries were cultured in such media, meiosis was inhibited. These results infered that the testis during early stages of differentiation secretes a substance with a meiosis-preventing effect, which we have called the meiosis-preventing substance, MPS. However, when culture media of puberty testes of mice and bull were tested in a similar way little or no inhibition of meiosis was seen in the fetal ovaries. In contrast, these media contained a MIS-activity (Grinsted, Byskov and Andreasen, 1979). It
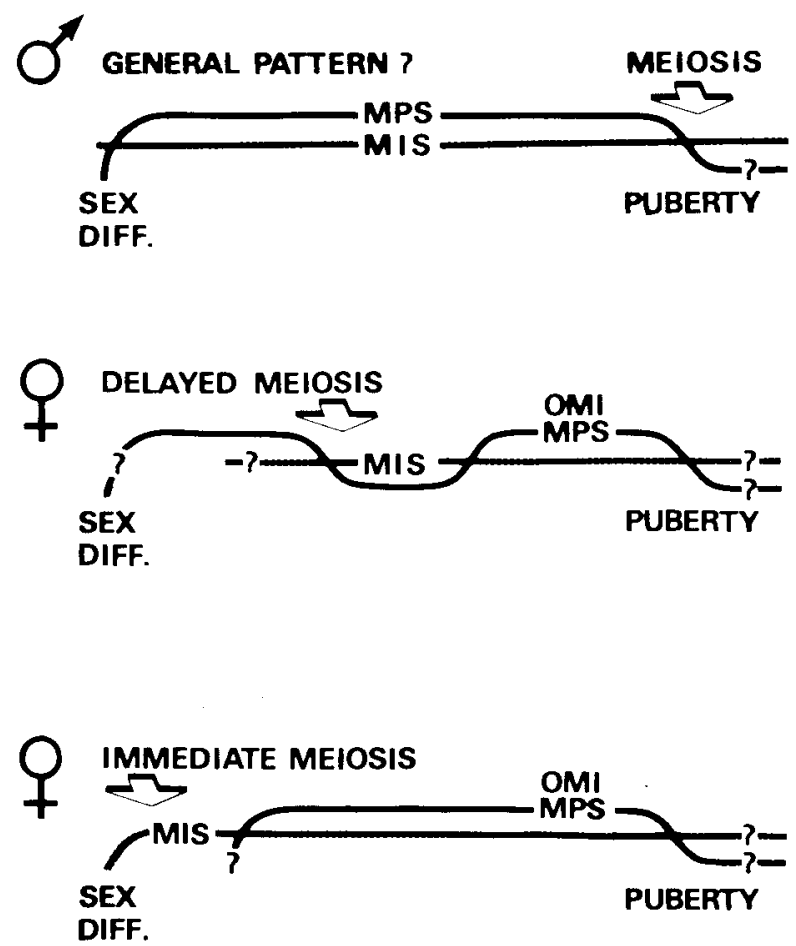

FIG. 1. - Hypothetical models for regulation of meiosis in males and females are shown.

In the male a general pattern is proposed. At the time of gonadal sex differentiation MIS as well as MPS is present in the testis. The influence of MPS overpowers MIS until the time of puberty when the MPS decreases to low levels (or eventually disappears?) allowing MIS to function. Two types of female models are shown : one in which the onset of meiosis occurs much later than the gonads are sex differentiated, delayed meiosis, and the other, in which meiosis and sex differentiation occur simultaneously, immediate meiosis.

In « delayed meiosis " high levels of MPS could be responsible for the prevention of meiosis in a period after gonadal sex differentiation. When the level of MPS drops below that of MIS, meiosis starts. This pattern would resemble that of the testis. Species with " delayed meiosis 》 also have some morphological and hormonal resemblance with males (see the text). When follicles form, the level of MPS - or OMI - rises, thus being responsible for maintaining the oocyte in the resting diplotene stage. Changes in the levels between MPS/MIS at puberty in the large follicles may be important for resumption of meiosis.

In species with « immediate meiosis » only MIS is present right after sex differentiation, thus inducing meiosis. When follicles form, the MPS/OMl level increases following the pattern described in "delayed meiosis".

The relationship between MIS, MPS/OMI and sex steroid hormones is discussed in the text. 
appears that the MPS is active within the differentiating fetal testis, but that its activity or secretion is absent or low at puberty. We suggest, that MPS participates in preventing meiosis from occurring until puberty (fig. 1).

It is tempting to speculate whether low levels of MPS are present within the testicular tubules throughout life, and thus responsible for mainfaining the stem cell pool of spermatogonia.

\section{Induction of meiosis in females.}

In many species it has been noticed that the germ cells which first enter meiosis are those situated at the inner border of the ovarian cortex (Winiwarter and Sainmont, 1909 ; Byskov, 1975). These oogonia are the first to make contact with the mesonephric-derived cells previously called rete cells (Byskov, 1978c). The importance of the mesonephric system in triggering meiosis and the formation of follicles was shown in studies of grafted fetal ovaries with and without the attached mesonephric system : if the grafted fetal ovary was detached from the mesonephric connection early enough, meiosis (Byskov, 1974) as well as the formation of follicles (Byskov et al., 1977) was prevented. In cultures of hamster ovaries, meiosis could be induced prematurely by co-cultured older ovaries with germ cells in meiosis (Fajer, 1979). The meiosisinducing substance described above, is presumably secreted from the mesonephricderived cells in the female as well as in the male. MIS is therefore probably present in the gonads of both sexes in which meiosis is occurring.

The question arises : what is triggering the secretion of MIS, and why does meiosis in some species start early in fetal life (humans and mice) and much later in others (rabbits and pigs). Tarkowski (1969) suggested, that some intrinsic germ cell factors might be operating as a physiological clock to trigger the onset of meiosis.

\section{Meiotic arrest in females.}

The fate of oocytes depends on their success in reaching the diplotene stage and being enclosed in a follicular unit (Peters, 1978). The diplotene oocyte apparently has

FIG. 2a. - Fetal rabbit testis removed on day 16 p. c. and culfured close to a 3-day old rabbit ovary (see fig. 4) for 7 days. The testicular tubules contain centrally placed giant germ cells (see fig. $2 b$ ). $\times 380$.

FIG. 2b. - Close-up of the giant germ cells shown in figure $2 . \times 960$.

FIG. 3. - Germ cell in leptotene stage and two lorge germ cells in preleptotene condensation stages of a fetal control testis culfured for 7 days from day 16 p. c. $\times 960$.

FIG. 4. - Oocyfes in early leptotene and zygotene stages of the 3-day old ovary mentioned in figure 2. $\times 960$.

FIG. 5a. - Part of human fetal ovary, 10 weeks of gestation age. The organ is compact with oocytes distributed unformly within the tissue. A small part of mesonephric cells, which previously has been termed connecting rete ovarii, is indicated by the arrow. Epon-section, $1 \mu \mathrm{m}$, stained with tolvidin-blue. $\times 90$.

FIG. 5b. - Higher magnification of the area shown in figure 5a, where mesonephric cell cords enter the ovary. Oocytes and somatic cells lie close together. $\times 380$. 
to be provided with some granulosa cells, since naked oocytes do not exist in the adult ovary. The proper supply of granulosa cells was suggested to be crucial for oocyte survival (Ohno and Smith, 1964). What is happening when the diplotene oocyte is being separated from its surroundings by the granulosa cells? Is this responsible for the diplotene arrest? Only little is known about the mechanisms which regulate the arrest and the onset of the growth of oocyte and granulosa cells. However, in larger follicles the resumption of meiosis is apparently kept in abeyance by an oocyte maturation inhibitor, OMl, present in the follicular fluid (Tsafriri and Channing, 1975; Tsafriri, Pomerantz and Channing, 1976). OMl is secreted by the granulosa cells, and is present in higher concentrations in the smaller antral follicles than in the larger ones (Tsafriri and Channing, 1975). It has been proposed that an inhibitor, a meiosispreventing substance (MPS) is functioning already from the beginning of follicular formation and that if is responsible for the oocyte arrest in diplotene stage (Byskov, $1978 a)$.

Thus in the female as well as in the male the two substances, MIS and MPS, may be participating in initiating the onset and the arrest of meiosis in germ cells (fig. 1).

\section{Capacity of germ cells to enter meiosis prematurely.}

Premature meiosis occurs in fetal male germ cells of different species (cats: Ohno et al., 1962 ; humans : Luciani ef al., 1977 ; mice : Byskov, 1978a) but similar premature meiosis has not been seen in ovaries. In the rabbit in which gonadal sex differentiation precedes the onset of meiosis by about two weeks, one might expect to find some germ cells in meiosis during that period, if a meiosis-inducing substance is present in the mesonephric system, as it is, for example, in the fetal mouse. However, examinations of serially sectioned rabbit ovaries and testes of different fetal ages (from day 15 p. c. to day 30 p. c.), revealed no germ cells in meiosis. But in 1 and 3-day old rabbits preleptotene condensation stages appeared in the gonads of both sexes as well as the more advanced meiotic stages in the ovary (Devictor-Vuillet ef al., 1973). Why is meiosis not triggered in gonads of fetal rabbits? Must germ cells achieve a certain stage of maturation before they can respond to MIS ? Is MIS present at all ? Or is MPS blocking meiosis?

In order to test some of these possibilities we cultured 16-day old fetal rabbit gonads with some attached mesonephric tubules close to 3 -day old infant rabbit ovaries. The material included 5 pairs of fetal testes and 5 pairs of fetal ovaries. One gonad of each pair was combined with the 3-day old ovary. The contralateral gonad

FIG. 6. - Ovary of an 18-day old fefal rabbit. The central area holds a network of cell-cords containing somatic and germ cells. Eponsection $1 \mathrm{\mu m}$, toluidin-blue. $\times 90$.

FIG. 7. - Testis of on 18-day old fetal testis with festicular cords. Epon-section $1 \mu \mathrm{m}$, toluidinblue. $\times 90$.

FIG. 8a. - Ovary of a 42-day old fetal pig with distinct well defined cords which contain most of the germ cells. $\times 90$.

FIG. $8 b$. - Higher magnification of the fetal pig ovary with germ cells confined to cell-cords. $\times 380$. 
स⿻ $36: 0.0432 .04305$

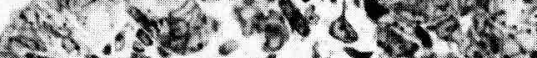

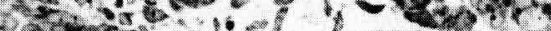

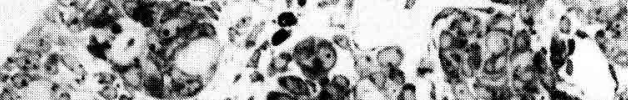

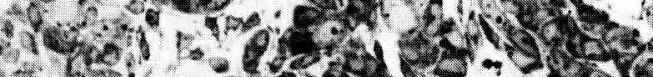

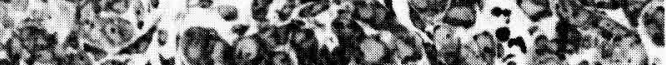

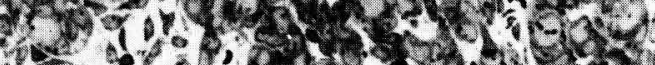

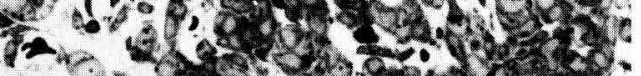

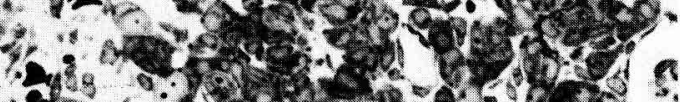

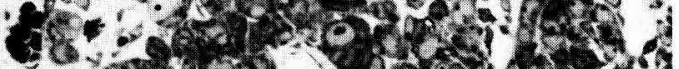
bo: cus

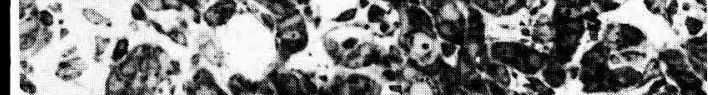

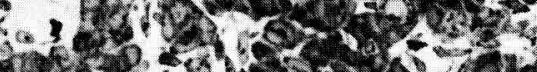

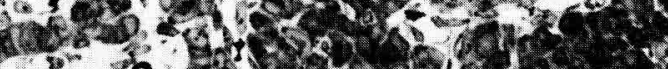

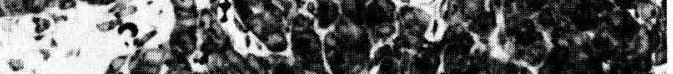
3.

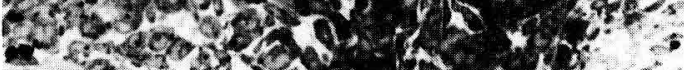

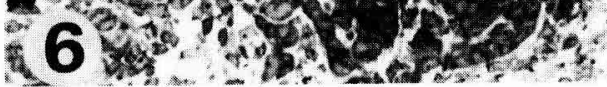

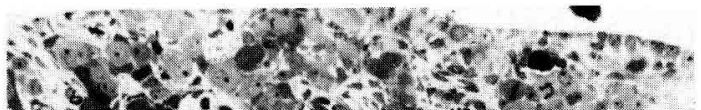

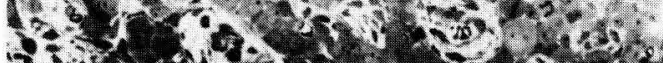

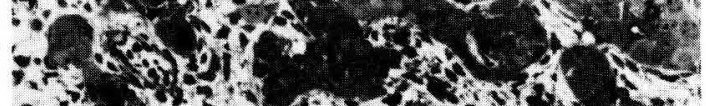

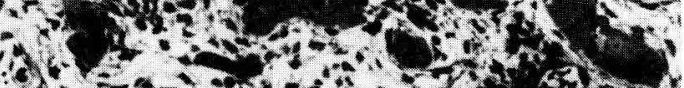

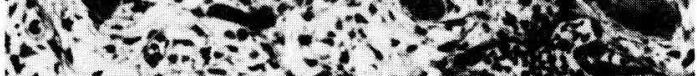

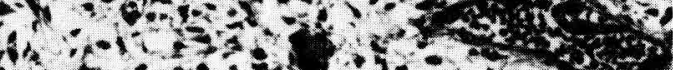

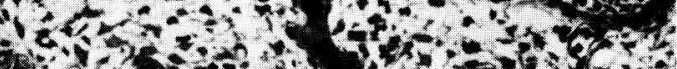

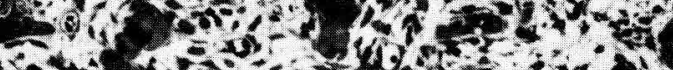

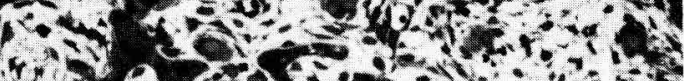

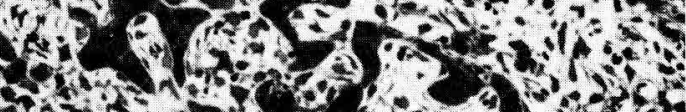

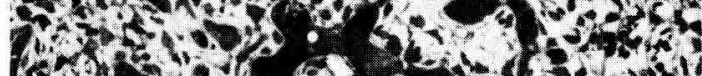

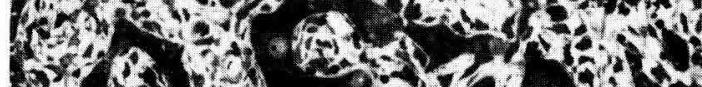

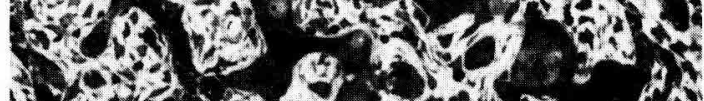

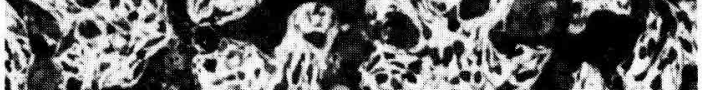

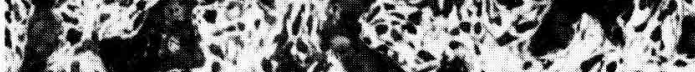

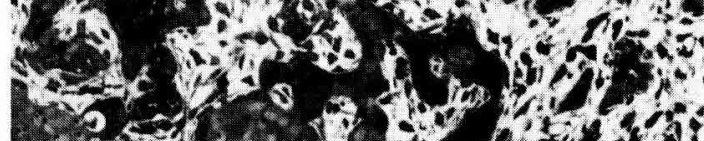

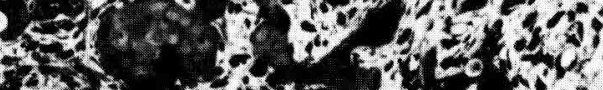
$8 a^{2}, 40+6$

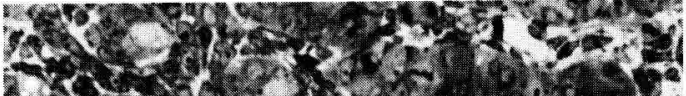

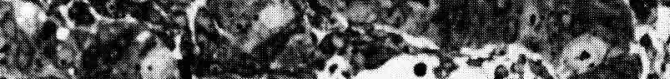

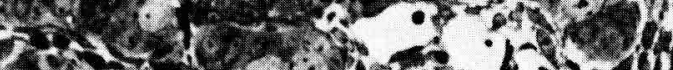

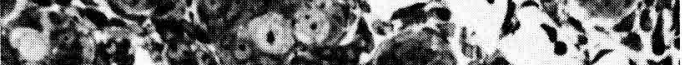

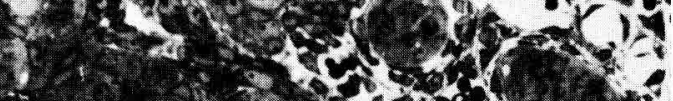

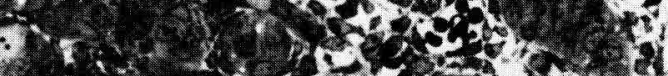

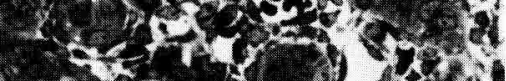

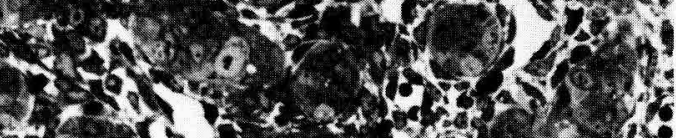

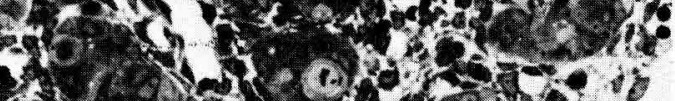

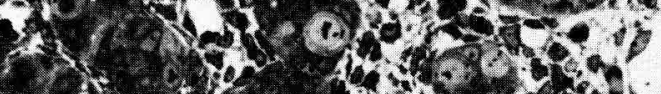

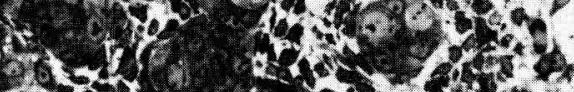

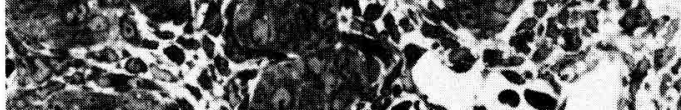

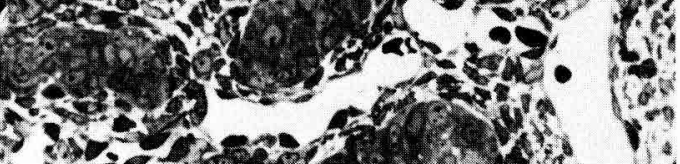

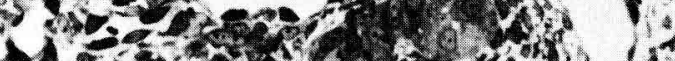

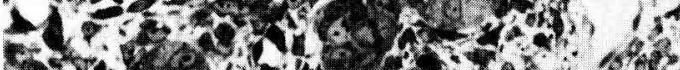

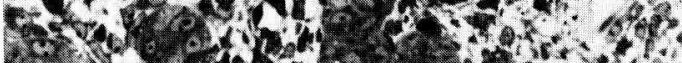

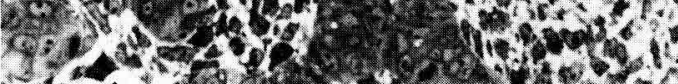

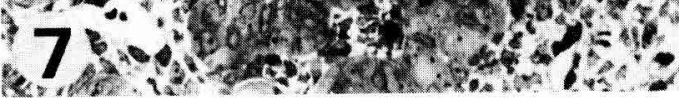

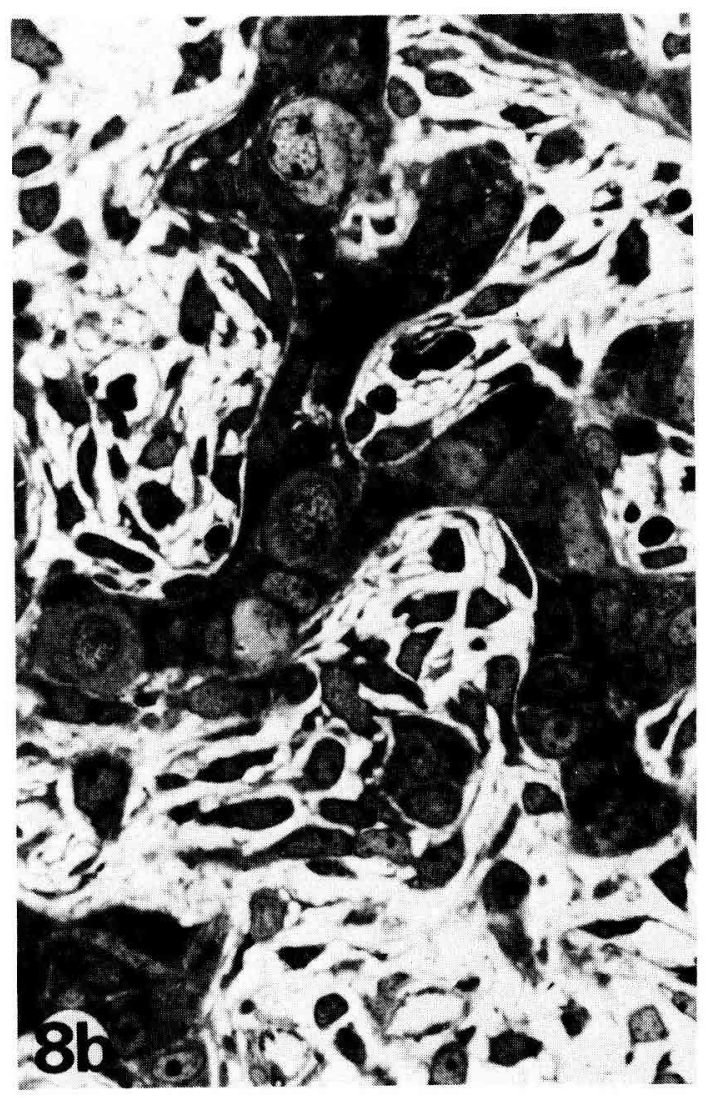


from each fetus and 3-day old animal served as controls and was cultured alone in a separate culture dish. The culture medium was Eagle's modified Minimum Essential Medium with penicillin $(50 \mathrm{lU} / \mathrm{ml})$, streptomycin $(50 \mu \mathrm{g} / \mathrm{ml})$ and $2 \mathrm{mM}$ glutamin, $\mathrm{pH}$ 7.4. The cultures were grown at $37^{\circ} \mathrm{C}$ in a gas atmosphere of $5 \mathrm{p} .100 \mathrm{CO}_{2}$ in 95 p. 100 air. After 7 days in culture, the tissues were fixed in Zenker, embedded in paraffin, serially sectioned at $5 \mu \mathrm{m}$ and stained with PAS and hematoxylin. The sex of each fetus was established by histological examination of the control gonad.

Most germ cells of the fetal gonads were big and had a nuclear diameter 1/1/2 times larger than that of the meiotic oocytes in the infant ovary (figs. 3, 4). In all the fetal cocultured testes giant germ cells were present in the center of the testicular cords (fig. 2a). Most of these big germ cells appeared to be in early leptotene stages (fig. $2 b$ ). Also some of the other big germ cells in the experiments as well as in most of the controls of both sexes were in early leptotene and occasionally in more advanced leptotene stages (fig. 3). Except for the giant cells of the experimental fetal testes the germ cells were similar in the co-cultured and the control gonads. The 3-day old ovary did not trigger meiosis in the fetal germ cells. It was merely the effect of being cultured which caused the fetal germ cells to enter preleptotene.

The fetal gonads did not impose any detectable, morphological inhibition of meiosis on the infant ovary, in which germ cells in different stages of meiosis were situated closely to the fetal tissues. Thus meiosis was not induced in the fetal germ cells by the infant ovary, and the fetal gonads did not inhibit meiosis in the infant ovary; a few germ cells in the cultured fetal gonads spontaneously entered the early stages of meiosis, indicating that already in fetal life rabbit germ cells are able to enter meiosis.

The negative results of the co-cultured rabbit gonads stimulated a comparative study of gonads of different species. We wished to explain why the female germ cells of some species do not enter meiosis immediately after gonadal differentiation, while others do. When gonadal sex differentiation and onset of meiosis are closely related in time, the process has been named « simultaneous meiosis » and when separated in time, the term « delayed meiosis » is used.

\section{6. "Simultaneous and delayed meiosis".}

In a review, Mauléon (1969) compared gonadal sex differentiation with the onset of meiosis in different species. Mice, humans, rats and guinea-pigs are examples of species with "simultaneous meiosis", and rabbits, pigs, cats, cows and ewes have « delayed meiosis». There seem to be profound morphological differences between the ovaries of species with simultaneous and delayed meiosis during early sex differentiation. In figures $5 a, b, a 10$-week old human ovary is shown. This ovary, like that of the fetal mouse (see Peters, 1976) and the hamster (Weakley, 1967), is a compact organ with germ cells and somatic cells distributed freely among each other. The ovaries of an 18-day old fetal rabbit (fig. 6) and of a 42-day old fetal pig (fig. 8a) are quite different : the organs are not solid like the human ovary, but contain distinct cords which enclose the germ cells (fig. $8 b$ ). The rabbit as well as the pig ovaries resemble somewhat the male gonads of the same ages (fig. 7).

Also in respect to the ability to secrete sex steroids, species with « simultaneous meiosis » deviate from those with « delayed meiosis ». No significant amounts of sex 
steroids are secreted by the newly differentiated ovaries of humans (for review see Resko, 1977) and rats and mice (Block et al., 1974). However, within the period between gonadal sex differentiation and the onset of meiosis, high levels of estrogens are detected in rabbits (Milewich, George and Wilson, 1976), cows (Shemesh et al., 1978) and sheep (Mauléon, Bézard and Terqui, 1978). Thus the species with « delayed meiosis » which have been studied until now, secrete significant amounts of estradiol during early ovarian differentiation in contrast to species with «simultaneous meiosis ". It is also evident that the secretion of estradiol drops to very low levels immediately before meiosis starts in species with delayed meiosis (see references above). Could it be possible that the ovarian secretion of estradiol in species with delayed meiosis is related to the absence of meiosis? Could the functioning of MPS be favored by the presence of sex steroids?

There seems to be a correlation between the ability to secrete sex steroids and the isolation of germ cells into cords, tubules or follicles. The testes start to secrete hormones when the gonocytes are enclosed in testicular cords; ovaries with « delayed meiosis " secrete estradiol and have germ cells in the cords; and ovaries with follicle-enclosed oocytes secrete sex steroids.

One of the basic events in gonadal organogenesis is the isolation of germ cells. Are free germ cells themselves able to prevent or interfere, for example, with the hormone production of the interstitial cells? It might be possible that the creation of a specific micromilieu which contains the germ cells, is necessary for the induction and maintenance of the hormonal activity surrounding these areas.

4th Workshop on « Development and maturation of the reproductive organs and functions 》" Luynes, France, octobre 1978.

Acknowledgments. - The technical assistance of Anni Bang Kristensen, Inga Husum, Anne Lise Mohr, Jette Lise Hansen, Lene Ahrenst and Paul Riel is gratefully acknowledged. This investigation is supported by The Danish Medical Research Council and Nordic Insulin Foundation. I wish to thank Dr. Niels Björkman, The Royal Veterinary and Agriculture University, Copenhagen, for providing the fetal pig gonads.

Résumé. Les milieux de culture qui contiennent, soit une substance pouvant induire la méiose (substances inductrices de la méiose, $M I S$ ), soit empêchant la méiose (substances de prévention de la méiose, MSP) peuvent être obtenus à partir de différentes expérimentations.

«MIS » est présent dans les milieux de culture où se sont développés des tissus ovariens avec des cellules germinales en méiose, ou un épididyme fœtal ou un épididyme d'animal pubère ou des testicules. «MIS» est apparemment non spécifique d'une espèce puisque le milieu contenant «MIS » obtenu à partir de taureaux pubères induit la méiose dans les testicules indifférenciés de fœetus de souris.

II est conclu que «MIS » esł présent dans le tissu dérivé du mésonéphros dans les gonades où la méiose survient. De plus, un « MPS » dans le tissu festiculaire (dans les cordons testiculaires ?) pourrait participer en empêchant la méiose dans le testicule fœetal.

Cependant, un résultat négatif de test d'activité « MIS » était obtenu dans une expérience avec des gonades de lapin : la méiose n'était pas induite dans les gonades fœtales par du tissu d'ovaire infantile contenant des cellules germinales en méiose. Ceci conduit 
à des recherches comparatives dans les gonades d'espèces chez lesquelles le début de la méiose et la différenciation sexuelle gonadique coïncident dans le temps, « méiose simultanée », et chez des espèces comme la lapine où le début de la méiose chez la femelle est retardé par rapport à la différenciation sexuelle, « méiose retardée ». Dans les espèces d̀ «méiose retardée » les cellules sont incluses dans les structures cordonales pendant la période entre la différenciation sexuelle ef le début de la méiose. Au cours de cette période, ces espèces produisent aussi des stéroïdes sexuels. Dans les espèces avec « méiose simultanée » les cellules germinales femelles sont distribuées librement dans le cortex, et aucune hormone stéroïde n'est produite au cours de la période qui suit la différenciation sexuelle. La signification de ces faits est discutée en relation avec la régulation de la méiose.

\section{References}

BLOCK E., GUPTA C., FELDMAN S., VAN DAMME O., 1974. Testosterone production by testes of fetal rats and mice. Coll. INSERM, 32, 177-190.

BYSKOV A. G., 1974. Does the rete ovarii act as a trigger for the onset of meiosis? Nature (Lond.), 252, 396-397.

BYSKOV A. G., 1975. The role of the rete ovarii in meiosis and follicle formation in the cat, mink and ferret. J. Reprod. Fert., 45, 201-209.

BYSKOV A. G., 1978a. The meiosis inducing interaction between germ cells and rete cells in the fetal mouse gonad. Ann. Biol. anim. Biochim. Biophys., 18, 327-334.

BYSKOV A. G., 1978b. Regulation of initiation of meiosis in fetal gonads. Int. J. Andrology, suppl. 2, 29-38.

BYSKOV A. G., 1978c. The anatomy and ultrastructure of the rete system in the fetal mouse ovary. Biol. Reprod., 19, 720-735.

BYSKOV A. G., SAXEN L., 1976. Induction of meiosis in fetal mouse testis in vitro. Dev. Biol., 52, 193-200.

BYSKOV A. G., SKAKKEBAEK N. E., STAFANGER G., PETERS H., 1977. Influence of ovarian surface epithelium and rele ovarii on follicle formation. J. Anot., 123, 77-86.

DEVICTOR-VUILLET M., LUCIANI J. M., STAHL A., 1973. Etude des stades de début de la méiose chez l'ovocyte de lapin. Comparaison avec l'ovocyte humain. Ann. Biol. anim. Biochim. Biophys., 13 H. S., 74-78.

FAJER A. B., 1979. The induction of meiosis in foetal hamster gonads and isolated germ cells by new born ovaries in vifro. Ann. Biol. anim. Bioch. Biophys., 19, 1273-1278.

GONDOS B., 1977. Testicular development, 1-37. In JOHNSON A. D., GOMES W. R., The testis, vol. 4, Adv. Physiol. Biochem. Function, Acad. Press, N. Y.

GRINSTED J., BYSKOV A. G., ANDREASEN M. P., 1979. Induction of meiosis in fetal mouse testis in vitro by rete testis obtained from pubertal mouse and bull testes. J. Reprod. Ferf. (in press).

HILSCHER W., MAKOSKI H. B., 1968. Histologische und autoradiographische Unfersuchungen zur «Präspermatogenese » und der «Spermatogenese " der Ratte. Z. Zellforsch., 86, 327-350.

JOST A., 1965. Gonadal hormones in sex differentiation of the mammalian foetus, 611-628. In Organogenesis. DE HAAN R. L., URSPRUNG H., Holt, Rinehart \& Winston, New York.

JOST A., 1970. Hormonal factors in the sex differentiation of the mammalian fœtus. Phil. Trans. roy. Soc. Lond. B., 259, 119-130.

JOST A., 1972. Becoming a male. Adv. Biosci., 10, 3-13.

JOST A., 1974. Sertoli cells and early testicular differentiation, 1-11. In Male fertility and sterility. MANCINE R. E., MARTINE L., Acad. Press, New York.

LUCIANI J. M., DEVICTOR M., STAHL A., 1977. Preleptotene chromosome condensation sfage in human fœetal and neonatal testes. J. Embryol. exp. Morph., 38, 175-186.

MAULÉON P., 1969. Oogenesis and folliculogenesis, 187-215. In COLE H. H., CUPPS P. T., Reproduction in domestic animals, Acad. Press, New York \& London.

MAULÉON P., BÉZARD J., TERQUI M., 1977. Very early and transient secretion of œstradiol-17 $\beta$ by foetal sheep ovary. In vitro study. Anim. Biol. anim. Bioch. Biophys., 17, 399-401.

MCLAREN A., CHANDLEY A. C., KOFFMAN-ALFARO S., 1972. A study of meiotic germ cells in the gonads of foetal mouse chimaeras. J. Embryol. exp. Morph., 27, 515-524. 
MILEWICH L., GEORGE F. W., WILSON J. D., 1976. Estrogen formation by the ovary of the rabbit embryo. Endocrinology, 100, 187-196.

O W. S., BAKER T. G., 1976. Initiation and control of meiosis in hamster gonads in vitro. J. Reprod. Fert., 48, 399-401.

OHNO S., SMITH J. B., 1964. Role of fetal follicular cells in meiosis of mammalian oocytes. Cyiogenesis, 3, 324-333.

OHNO S., STENIUS C., WEILLER C. P., TRUJILLO J. M., KAPLAN W. D., KINOSITA R., 1962. Early meiosis of male germ cells in fetal testis of Felis Domestica. Exp. Cell Res., 27, 401-404.

OZDZENSKI W., 1972. Differentiation of the genital ridges of mouse embryos in the kidney of adult mice. Arch. Anat. microsc. Morphol. exp., 61, 267-278.

PETERS H., 1976. Intrauterine gonadal development. Fertil. Steril., 27, 493-500.

PETERS H., 1978. Folliculogenesis in mammals. In JONES R., The vertebrate ovary : Comparative biology and evolution. Plenum, New York, London.

RESKO J. A., 1977. Fetal hormones and development of the central nervous system in primates. Adv. Sex Horm. Res., 3, 139-168.

SHEMESH M., AILENBERG M., MILAGUIV F., AYALON N., HANSEL W., 1978. Hormone secretion by cultured bovin pre- and post implantation gonads. Biol. Reprod. (in press).

TARKOWSKI A. K., 1969. Are genetic factors controlling sexual differentiation of somatic and germinal tissues of a mammalian gonad stable or labile ? In KRETCHMAR N., WALCHER D. N., Environmental influences on genetic expression. Biological and behavioral aspects of sexual differentiation, Fogarty int. Center Proc. no. 2, pp. 49-60.

TSAFRIRI A., CHANNING C. P., 1975. Influence of follicular maturation and culture conditions on the meiosis of pig oocytes in vitro. J. Reprod. Fert., 43, 149-152.

TSAFRIRI A., POMERANTZ S. H., CHANNING C. P., 1976. Porcine follicular fluid inhibitor of oocyle meiosis : Partial purification and characterization. Biol. Reprod., 14, 511-516.

WEAKLEY B. S., 1967. Light and electron microscopy of developing germ cells and follicle cells in the ovary of the golden hamster : twenty-four hours before birth to eight days post portum. J. Anat., 101, 435-459.

WINIWARTER H. von, SAINMONT G., 1909. Nouvelles recherches sur l'ovogenèse ef l'organogenèse de l'ovaire des mammifères (chat). Arch. Biol., 24, 373-431. 